\title{
Development and realization of lithium-ion battery modules for starting applications and traction of off-road electric vehicles
}

\author{
F. Vellucci ${ }^{1}$, G. Pede ${ }^{1}$, F. D’Annibale ${ }^{1}$, A. Mariani ${ }^{1}$, \\ R. Roncella ${ }^{2}$, R. Saletti ${ }^{2}$, F. Baronti ${ }^{2}$, G. Fantechi ${ }^{2}$ \\ ${ }^{1}$ Italian National Agency for New Technologies, Energy and Sustainable Economic Development (ENEA), Via \\ Anguillarese, 301 -00123 S. Maria di Galeria (RM) - ITALY, francesco.vellucci@enea.it \\ ${ }^{2}$ University of Pisa, Via G. Caruso, 16-56122 Pisa-ITALY, roberto.roncella@iet.unipi.it
}

\begin{abstract}
The paper describes the development and realization of standard battery modules $12 \mathrm{~V}$, made by $\mathrm{LiFePO}_{4}$ cells selected in a previous study by ENEA and the University of Pisa. Module means the group of four cells series connected, the electronic battery management system, the thermal management system and the mechanical case. Standard means that the same battery module can be used for different applications: in fact, the previous study showed that three standard battery modules, $30 \mathrm{Ah}$ (little size), $60 \mathrm{Ah}$ (medium size) and $100 \mathrm{Ah}$ (large size), are sufficient to reach the levels of voltage/capacity requested by the most part of the applications in the field of the starting/auxiliary supply batteries (also for the nautical sector) and traction of off-road electric vehicles. More units of standard modules can be series/parallel connected to build complete battery systems able to satisfy the required performances.

The development and realization of the modules mostly consisted of testing the selected cells to verify their suitability for the above mentioned applications, to make a thermal battery characterization so to define the thermal management system, to develop an electronic battery management system and to build a mechanical case. The paper shows all these aspects in detail.
\end{abstract}

Keywords: electrification, off-road vehicles, lithium battery, battery module, $\mathrm{LiFePO}_{4}$, battery management system

\section{Introduction}

Among means of transportation, a large portion is occupied by off-road vehicles used in a variety of commercial and industrial applications. These vehicles include mobile work machines for various applications, such as building sites, earth moving, street cleaning, as well as agriculture, horticulture, greenhouse, and gardening. A diesel engine commonly powers off-road vehicles. The replacement or the combination of the internal combustion engine with an electric motor might be a remarkable step toward energy sustainability by reducing $\mathrm{CO}_{2}$ emissions and by improving energy utilization efficiency [1] [2] [3].

A recent study made by ENEA on the Italian market for mobile work machines gives a good idea of the relevance of these kinds of vehicles and the impact of their electrification [4]. It shows the surprising conclusion that at 2020 the battery market for electric mobile work machines could be $25 \%$ of the batteries used in electric cars. Two 
capacity levels, $120 \mathrm{Ah}$ and $180 \mathrm{Ah}$, and three voltages, $48 \mathrm{~V}, 96 \mathrm{~V}$, and $192 \mathrm{~V}$, are sufficient for the electrification of the different families of mobile work machines, as shown in Fig.1.

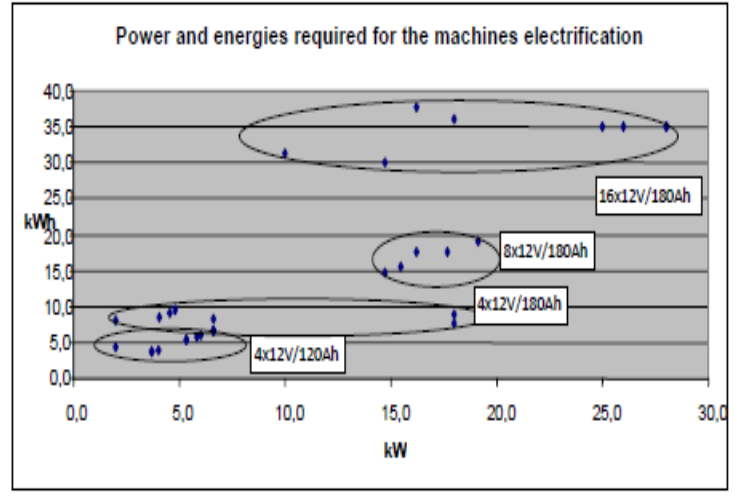

Figure 1: Power and energy required for the electrification of off-road vehicles

The main problems that slow down the large diffusion of the electric vehicles are the high initial costs, mainly due to the battery cost and the short runtime. A valid solution to reduce costs is the adoption of standard modules.

Defining the standard modules implies to establish the type of technology and the main electric characteristics, voltage and capacity. About the type of technology, the $\mathrm{LiFePO}_{4}$ was chosen as cathode chemistry because of safety and costs [4]. Adopting $12 \mathrm{~V}$ as nominal voltage of the module and three values of capacity, $30 \mathrm{Ah}$, $60 \mathrm{Ah}$, and $90 \div 100 \mathrm{Ah}$, it is possible to realize standard modules (module $12 \mathrm{~V}-30 \mathrm{Ah}$, little size; module $12 \mathrm{~V}$ - $60 \mathrm{Ah}$, medium size; module $12 \mathrm{~V}-90 \div 100 \mathrm{Ah}$, large size) which can be used, individually or series/parallel connected, to satisfy all the applications above-mentioned [4]. On the other hand, $12 \mathrm{~V}$ is the standard voltage for starting batteries and the $\mathrm{LiFePO}_{4}$ chemistry was proved to be the best solution for the application as starting lighting ignition batteries [5]. This is due to the compatibility with the working voltages of the electric suppliers commonly used in the vehicles, the big current capacity (the so called "cold cranking amperes", CCA), the particular conditions of the working environment (high temperature and vibrations). The series connection of four $\mathrm{LiFePO}_{4}$ cells equals the working voltages of the lead battery currently used as starting lighting ignition batteries on board the vehicles. This is not possible with other lithium batteries. Thus, the defined standard module can also be used as starting lighting ignition battery instead of the equivalent lead battery and this is another important factor of standardization. The standard modules were realized by four cells $\mathrm{LiFePO}_{4}$ series connected. The main characteristics of the cells used in the standard modules are shown in Table 1,2 and 3.

Table 1: Main characteristics of the cell for the little size module

\begin{tabular}{|c|c|c|}
\hline \multicolumn{2}{|l|}{ Param } & Value \\
\hline \multicolumn{2}{|l|}{ Voltage [V] } & 3.2 \\
\hline \multicolumn{2}{|c|}{ Nominal capacity $[\mathrm{Ah}]$} & 30 \\
\hline \multicolumn{2}{|c|}{ Dimensions $(\mathrm{L} \times \mathrm{W} \times \mathrm{H})[\mathrm{mm}]$} & $103 \times 58 \times 168$ \\
\hline \multicolumn{2}{|c|}{ Weight $[\mathrm{kg}]$} & 1.15 \\
\hline \multicolumn{2}{|l|}{ Energy [Wh] } & 96 \\
\hline \multicolumn{2}{|c|}{ Energy density $\left[\mathrm{Wh} / \mathrm{dm}^{3}\right]$} & 95 \\
\hline \multicolumn{2}{|c|}{ Specific energy [Wh/kg] } & 83 \\
\hline \multicolumn{2}{|c|}{ Working temperature (discharge) } & $-20 \div+65^{\circ} \mathrm{C}$ \\
\hline \multicolumn{2}{|c|}{ Working temperature (charge) } & $0 \div+45^{\circ} \mathrm{C}$ \\
\hline \multirow{3}{*}{$\begin{array}{l}\text { Discharge @ } \\
+23^{\circ} \mathrm{C}\end{array}$} & $\begin{array}{l}\text { Max continuous } \\
\text { current }[\mathrm{A}]\end{array}$ & 90 \\
\hline & $\begin{array}{l}\text { Peak current @ } \\
60 \mathrm{sec}[\mathrm{A}]\end{array}$ & 150 \\
\hline & $\begin{array}{l}\text { Cut-off voltage } \\
\text { [V] }\end{array}$ & 2.5 \\
\hline \multirow{3}{*}{$\begin{array}{l}\text { Charge @ } \\
+23^{\circ} \mathrm{C}\end{array}$} & Charge method & $\begin{array}{l}\mathrm{CC} / \mathrm{CV} \\
(3.65 \mathrm{~V})\end{array}$ \\
\hline & $\begin{array}{l}\text { Max charge } \\
\text { current }[\mathrm{A}]\end{array}$ & 30 \\
\hline & $\begin{array}{l}\text { Cut-off voltage } \\
{[\text { V] }}\end{array}$ & 3.85 \\
\hline
\end{tabular}

Table 2: Main characteristics of the cell for the medium size module

\begin{tabular}{|c|c|c|}
\hline \multicolumn{2}{|l|}{ Param } & Value \\
\hline \multicolumn{2}{|c|}{ Voltage [V] } & 3.2 \\
\hline \multicolumn{2}{|c|}{ Nominal capacity $[\mathrm{Ah}]$} & 60 \\
\hline \multicolumn{2}{|c|}{ Dimensions $(\mathrm{L} \times \mathrm{W} \times \mathrm{H})[\mathrm{mm}]$} & $114 \times 61 \times 203$ \\
\hline \multicolumn{2}{|c|}{ Weight $[\mathrm{kg}]$} & 2.04 \\
\hline \multicolumn{2}{|c|}{ Energy [Wh] } & 192 \\
\hline \multicolumn{2}{|c|}{ Energy density $\left[\mathrm{Wh} / \mathrm{dm}^{3}\right]$} & 136 \\
\hline \multicolumn{2}{|c|}{ Specific energy [Wh/kg] } & 94 \\
\hline \multicolumn{2}{|c|}{ Working temperature (discharge) } & $-20 \div+65^{\circ} \mathrm{C}$ \\
\hline \multicolumn{2}{|c|}{ Working temperature (charge) } & $0 \div+45^{\circ} \mathrm{C}$ \\
\hline \multirow{3}{*}{$\begin{array}{l}\text { Discharge @ } \\
+23^{\circ} \mathrm{C}\end{array}$} & $\begin{array}{l}\text { Max continuous } \\
\text { current }[\mathrm{A}]\end{array}$ & 180 \\
\hline & $\begin{array}{l}\text { Peak current @ } \\
60 \mathrm{sec}[\mathrm{A}]\end{array}$ & 300 \\
\hline & $\begin{array}{l}\text { Cut-off voltage } \\
\text { [V] }\end{array}$ & 2.5 \\
\hline \multirow{3}{*}{$\begin{array}{l}\text { Charge @ } \\
+23^{\circ} \mathrm{C}\end{array}$} & Charge method & $\begin{array}{l}\mathrm{CC} / \mathrm{CV} \\
(3.65 \mathrm{~V})\end{array}$ \\
\hline & $\begin{array}{l}\text { Max charge } \\
\text { current [A] }\end{array}$ & 60 \\
\hline & $\begin{array}{l}\text { Cut-off voltage } \\
\text { [V] }\end{array}$ & 3.85 \\
\hline
\end{tabular}


Table 3: Main characteristics of the cell for the large size module

\begin{tabular}{|c|c|c|}
\hline \multicolumn{2}{|l|}{ Param } & Value \\
\hline \multicolumn{2}{|l|}{ Voltage [V] } & 3.2 \\
\hline \multicolumn{2}{|c|}{ Nominal capacity [Ah] } & 100 \\
\hline \multicolumn{2}{|c|}{ Dimensions $(\mathrm{L} \times \mathrm{W} \times \mathrm{H})[\mathrm{mm}]$} & $163 \times 51 \times 278$ \\
\hline \multicolumn{2}{|c|}{ Weight $[\mathrm{kg}]$} & 3.40 \\
\hline \multicolumn{2}{|l|}{ Energy [Wh] } & 320 \\
\hline \multicolumn{2}{|c|}{ Energy density $\left[\mathrm{Wh} / \mathrm{dm}^{3}\right]$} & 138 \\
\hline \multicolumn{2}{|c|}{ Specific energy $[\mathrm{Wh} / \mathrm{kg}]$} & 94 \\
\hline \multicolumn{2}{|c|}{ Working temperature (discharge) } & $-20 \div+65^{\circ} \mathrm{C}$ \\
\hline \multicolumn{2}{|c|}{ Working temperature (charge) } & $0 \div+45^{\circ} \mathrm{C}$ \\
\hline \multirow{3}{*}{$\begin{array}{l}\text { Discharge @ } \\
+23^{\circ} \mathrm{C}\end{array}$} & $\begin{array}{l}\text { Max continuous } \\
\text { current }[\mathrm{A}]\end{array}$ & 300 \\
\hline & $\begin{array}{l}\text { Peak current @ } \\
60 \mathrm{sec}[\mathrm{A}]\end{array}$ & 500 \\
\hline & $\begin{array}{l}\text { Cut-off voltage } \\
{[\mathrm{V}]}\end{array}$ & 2.5 \\
\hline \multirow{3}{*}{$\begin{array}{l}\text { Charge @ } \\
+23^{\circ} \mathrm{C}\end{array}$} & Charge method & $\begin{array}{l}\mathrm{CC} / \mathrm{CV} \\
(3.65 \mathrm{~V})\end{array}$ \\
\hline & $\begin{array}{l}\text { Max charge } \\
\text { current [A] }\end{array}$ & 100 \\
\hline & $\begin{array}{l}\text { Cut-off voltage } \\
\text { [V] }\end{array}$ & 3.85 \\
\hline
\end{tabular}

\section{Electrical Battery Test}

Some samples of the selected batteries were tested under EUCAR procedures to verify the performances and the suitability to be used in the above mentioned applications. The testing activities were performed at the Battery Test Room of the "Low Environmental Impact Vehicles Laboratory" at ENEA Research Centre "Casaccia" by means of battery testers and climatic chambers. The following tests were performed:

- energy and capacity at different current rates and temperatures: in particular each sample was discharged with current rates respectively $1 \mathrm{C}, 2 \mathrm{C}, 3 \mathrm{C}$ at the temperatures $0{ }^{\circ} \mathrm{C},+23{ }^{\circ} \mathrm{C}$ and $+40{ }^{\circ} \mathrm{C}$;

- fast charge, according to the manufacturer's specification about the maximum continuative charging current rate, $1 \mathrm{C}$, which theoretically corresponds to the complete charge in one hour;

- internal resistance;

- cold cranking test to evaluate the suitability of the batteries for the application as starting lighting ignition batteries. The test was performed following the standard CEI EN 50342-1 "Lead batteries for starting applications - Part 1: General rules and test methods" adapted for lithium batteries.
The test results, resumed in the following figures, show the good behaviour of the cells and confirm their suitability for the selected applications.

\subsection{Capacity}

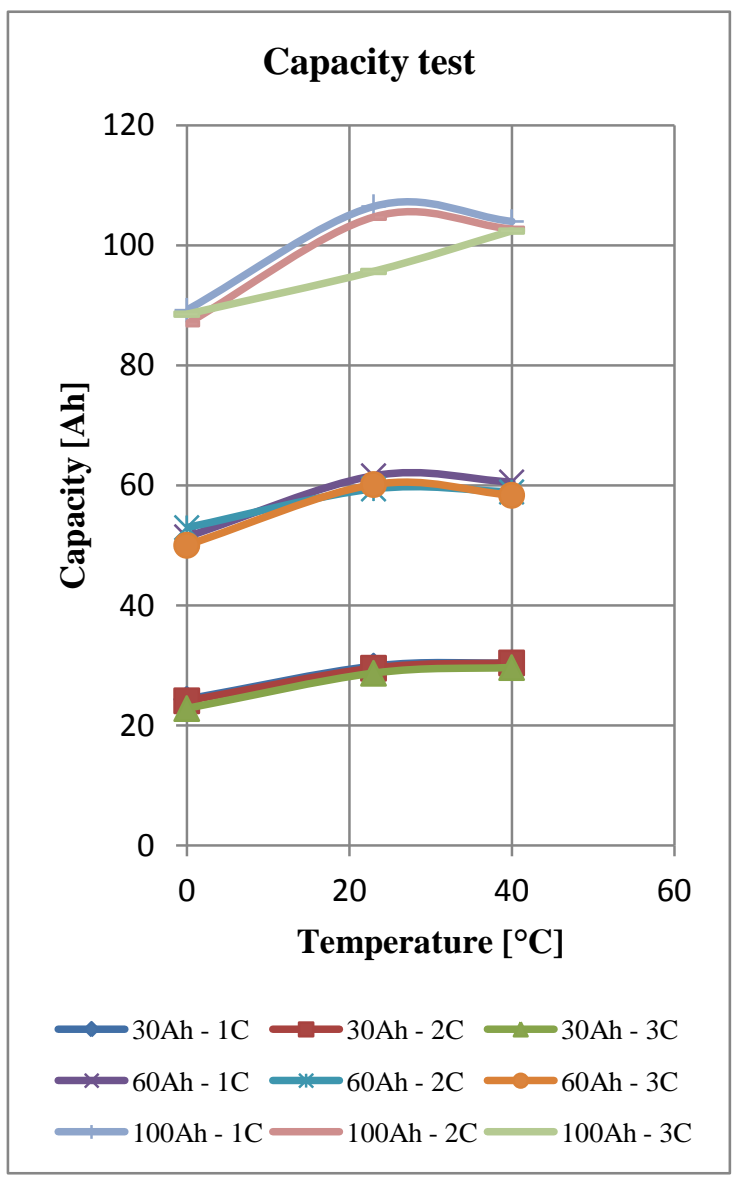

Figure 2: Results of the capacity test

At a given temperature, the capacity is not dependent on the current rate and at a given current rate the dependence of the capacity on the temperature is not so strong. The best performances are given in the field $+23 \div+40{ }^{\circ} \mathrm{C}$, while in the field of temperatures lower than +23 ${ }^{\circ} \mathrm{C}$ a reduction of capacity is registered, but it is completely normal.

\subsection{Fast charge}

The fast charge test consisted of a charge type $\mathrm{CC} / \mathrm{CV}$ (constant current/constant voltage) @ 1C, according to the specifications of the manufacturer. This charge theoretically corresponds to the complete charge of the battery in $1 \mathrm{~h}$. The voltage, current and temperature of the sample were monitored and registered during the test. A typical example of the test results is shown in Fig. 3. 


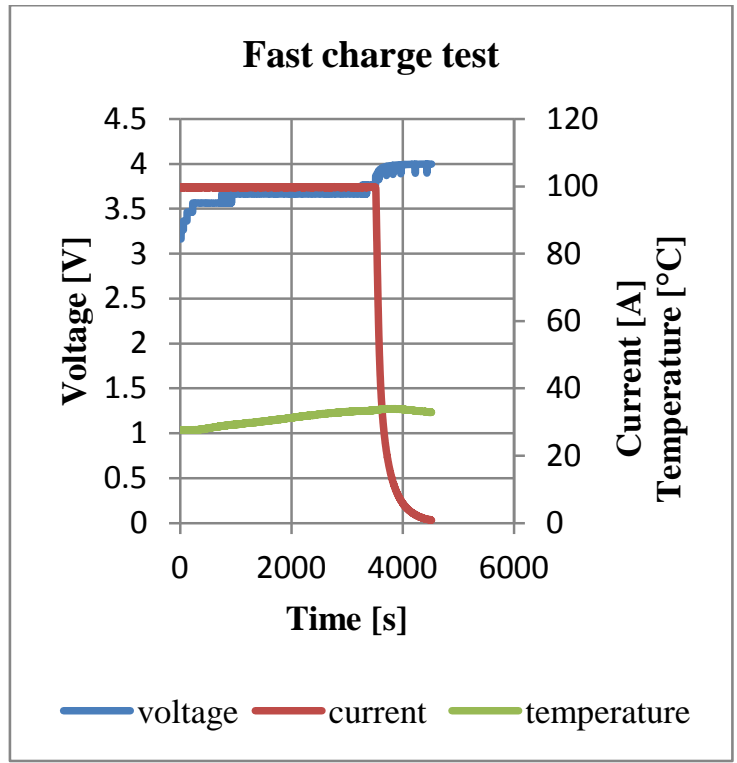

Figure 3: Results of the fast charge test

\subsection{Internal resistance}

The internal resistance is an important factor affecting heating and efficiency of the cell. The test is made by three current pulses, separated by little rest periods: the first and the second pulses are at $1 \mathrm{C}$ current rate, the first in discharge and the second in charge, while the third is in discharge at the maximum current value which can be used for $30 \mathrm{~s}$, according to the manufacturer. The sequence is shown in Fig. 4.

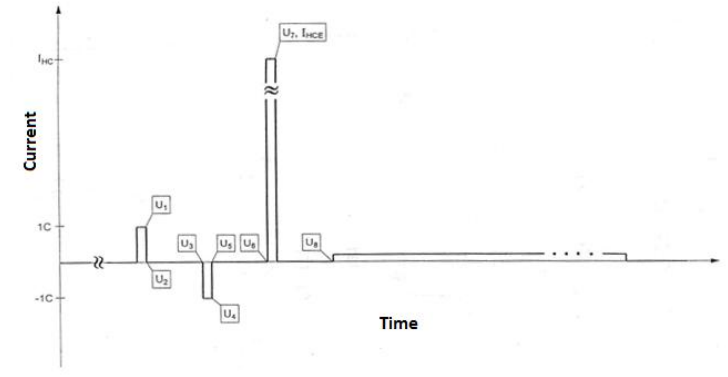

Figure 4: Current profile for the internal resistance test

Relating to the profile above, it is possible to identify eight characteristic points and define the following internal resistances:

- internal resistance in discharge:

$$
\mathrm{R}_{\Omega \text {,dch }}=\left(\mathrm{V}_{2}-\mathrm{V}_{1}\right) / \mathrm{I}_{1 \mathrm{C}}
$$

- overall internal resistance in discharge @ $1 \mathrm{C}$ :

$$
\mathrm{R}_{1 \mathrm{C}, \mathrm{dch}}=\left(\mathrm{V}_{3}-\mathrm{V}_{1}\right) / \mathrm{I}_{1 \mathrm{C}}
$$

- internal resistance in charge:

$$
\mathrm{R}_{\Omega \text {,cha }}=\left(\mathrm{V}_{4}-\mathrm{V}_{5}\right) / \mathrm{I}_{1 \mathrm{C}}
$$

- overall internal resistance in charge @ $1 \mathrm{C}$ :

$$
\mathrm{R}_{1 \mathrm{C}, \text { cha }}=\left(\mathrm{V}_{4}-\mathrm{V}_{6}\right) / \mathrm{I}_{1 \mathrm{C}}
$$

- overall internal resistance in discharge @ high C-rate:

$$
\mathrm{R}_{\mathrm{HC}, \mathrm{dch}}=\left(\mathrm{V}_{8}-\mathrm{V}_{7}\right) / \mathrm{I}_{\mathrm{HCE}}
$$

$\mathrm{I}_{\mathrm{HCE}}$ is the highest current which can be used for $30 \mathrm{~s}$, as for the manufacturer's specifications.

Fig. 5 shows a typical voltage and current profile registered during the internal resistance test and Table 4 gives an example of the results for a cell with capacity $100 \mathrm{Ah}$, at SOC $50 \%$, and $\mathrm{I}_{\mathrm{HCE}}$ current $500 \mathrm{~A}$.

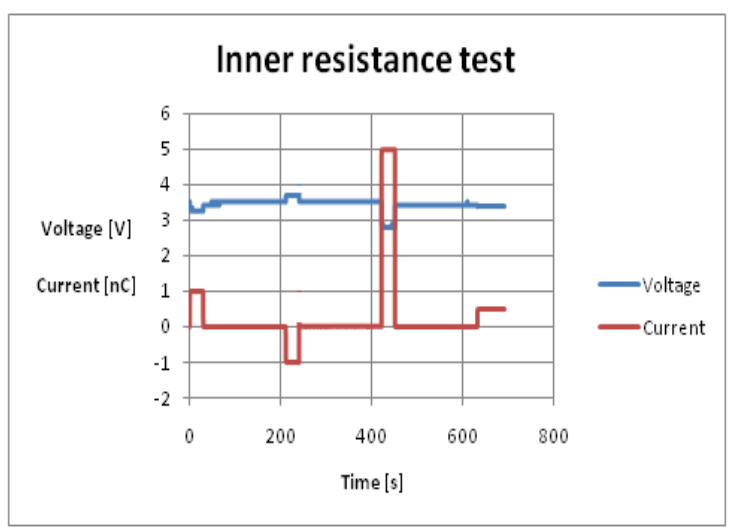

Figure 5: Voltage and current profile during the internal resistance test

Table 4: Values of internal resistance

\begin{tabular}{|c|c|}
\hline Param & Value $(\mathrm{m} \Omega)$ \\
\hline $\mathrm{R}_{\Omega, \text { dch }}$ & 1.66 \\
\hline $\mathrm{R}_{1 \mathrm{C}, \mathrm{dch}}$ & 2.66 \\
\hline $\mathrm{R}_{\Omega \text {,cha }}$ & 1.64 \\
\hline $\mathrm{R}_{1 \mathrm{C} \text {,cha }}$ & 1.65 \\
\hline $\mathrm{R}_{\mathrm{HC} \text {,dch }}$ & 1.26 \\
\hline
\end{tabular}

The internal resistance test gave good results and the values obtained agree with the specification of the manufacturer.

\subsection{Cold cranking test}

To qualify the standard modules as starting batteries, it was decided to verify the starting performance. The starting performance of lead batteries can be tested by means of the standard CEI EN 50342-1 "Lead batteries for starting applications - Part 1: General rules and test methods". In contrast, there is not a standard for lithium batteries: for this reason, it was applied the standard CEI EN 50342-1 with some adaptations. The standard requires to completely charge the battery, to make a rest of $24 \mathrm{~h}$, to put the battery in a climatic chamber at the temperature $-18{ }^{\circ} \mathrm{C}$, to make a discharge at current Icc (starting current, usually called Cold Cranking Ampere, specified by the manufacturer of the lead battery) within 2 minutes after the end of the cooling phase. After $10 \mathrm{~s}$ of discharge, the battery 
voltage must be measured and verified that it is not lower than the minimum voltage specified by the manufacturer and the current must be interrupted. After a rest of $10 \mathrm{~s}$, the battery must be discharged with a current $60 \%$ of $\mathrm{I}_{\mathrm{cc}}$, until the minimum voltage is reached. We performed the test at $-10{ }^{\circ} \mathrm{C}$, rather than at the really limit condition of $-18{ }^{\circ} \mathrm{C}$, because it seems to be a more realistic situation but hard enough at the same time. Further, the minimum voltage was set to $2.5 \mathrm{~V}$, according to the specification of the manufacturer, and the current rate was $4 \mathrm{C}$ (as a comparison with a lead battery $44 \mathrm{Ah}$, whose $\mathrm{I}_{\mathrm{cc}}$ current is $170 \mathrm{~A}$ ).

The typical voltage profile registered during the test is shown in Fig. 6: the voltage is always over the minimum value, which is reached at the end of the discharge at $60 \%$ of $\mathrm{I}_{\mathrm{cc}}$ only.

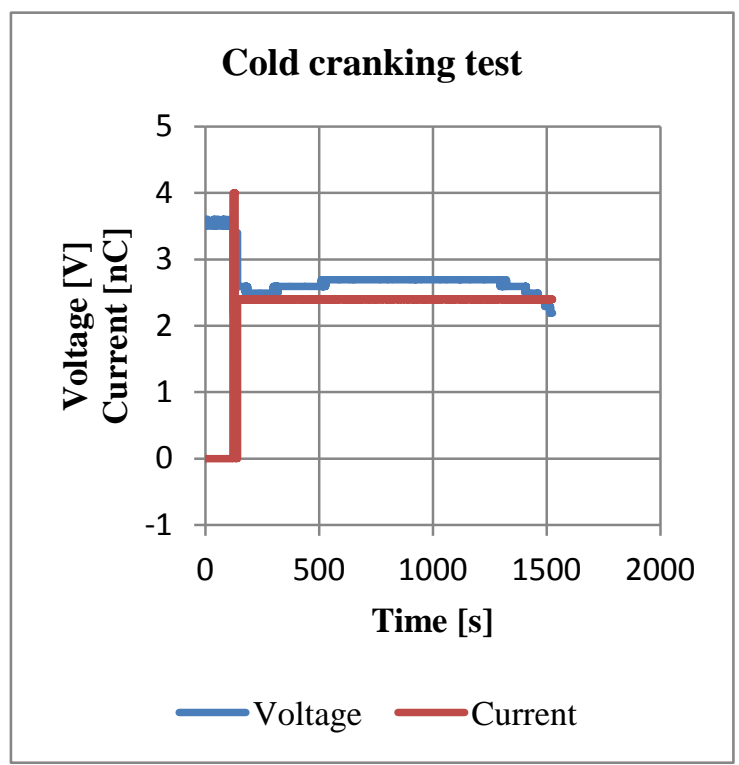

Figure 6: Typical voltage and current profile during the cold cranking test

\section{Thermal Management}

The electrical characterization tests at low temperatures showed that the cells do not need to be heated during the operation in cold conditions, so the thermal management system of the module is only a cooling system.

\subsection{Thermal battery characterization}

A thermal analysis on single cell level was performed to study the thermal distribution during charge and discharge without thermal conditioning and to evaluate if battery cooling during operation is needed. This was realized by the means of thermocouples and a thermo camera $320 \times 240$ pixel with thermal sensibility less than $0,1{ }^{\circ} \mathrm{C}$. A "hot point", where the highest temperatures are registered, was identified under the negative pole. This was a very valuable indication, which makes it possible to place the sensor used for the thermal monitoring in the optimal position to identify the highest temperature.
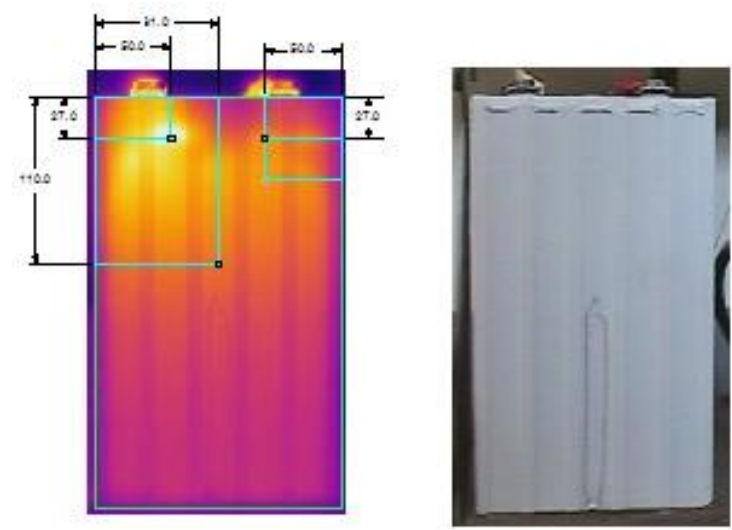

Figure 7: Typical results of the thermo graphic analysis during discharge, hot point on evidence

The thermal analysis also showed that the critical temperatures are reached only very close to the end of discharge at the maximum current rate, so this is the only phase where battery cooling is really necessary. Fig. 8 shows the typical temperature profile registered during a discharge at $300 \mathrm{~A}$ followed by a rest of $3600 \mathrm{~s}$ and a standard charge (CC/CV @ C/3) for the cell with capacity $100 \mathrm{Ah}$.

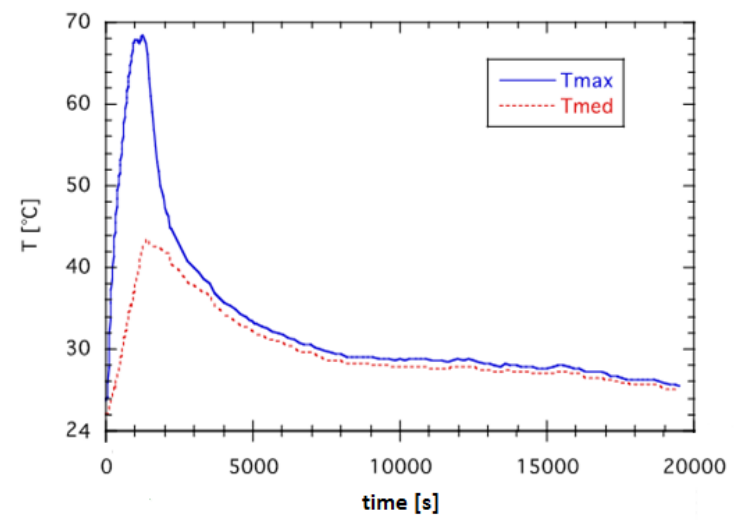

Figure 8: Temperature during discharge at maximum current rate

\subsection{Cooling plant with air}

An experimental test bed was realized to evaluate the performance of battery cooling by air. The plant is a duct equipped with two blowers at the inlet section. The fan speed is regulated to permit different air flows. A heater allows different working temperatures to be set. A right angle turn is used to create turbulence and mixing of the 
flow. The test section with four cells series connected is positioned at the end of the duct, where the condition of undisturbed flow is established.

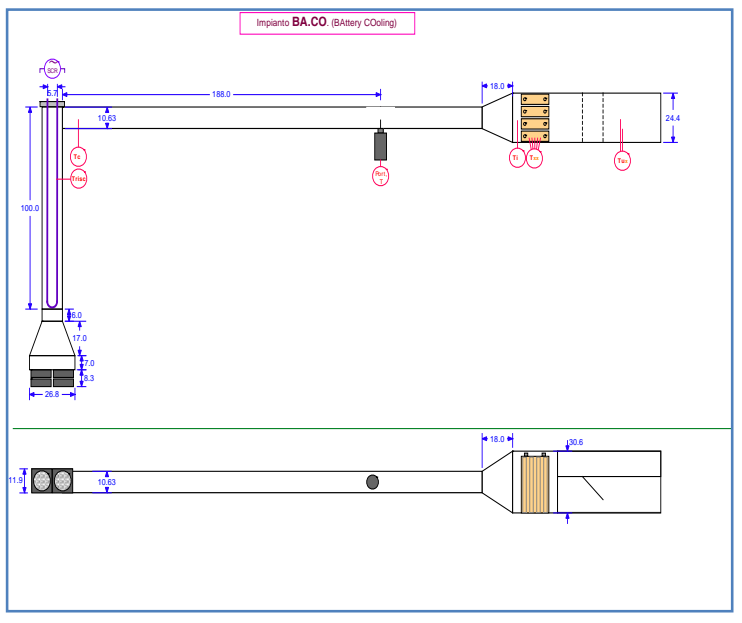

Figure 9: Scheme of the battery cooling plant with air

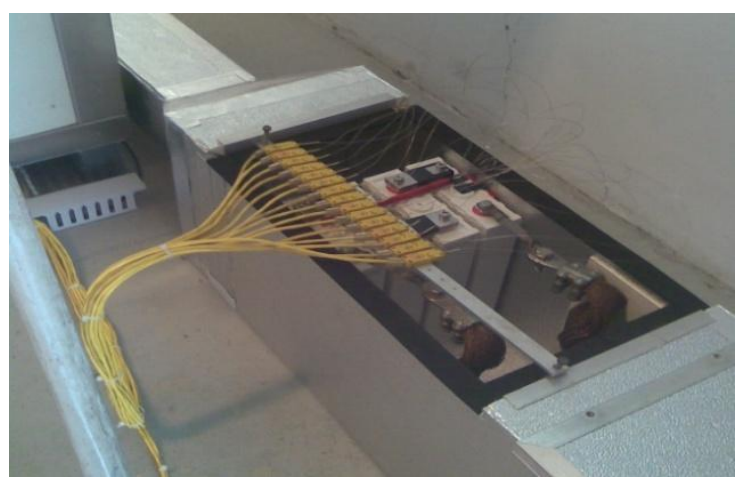

Figure 10: The cells with the thermal sensors inside the test section

Fig. 11 shows the position of the thermocouples on the cells: each cell is equipped with two thermocouples (one on each side of the cell) under the negative pole, where the thermo graphical analysis gave evidence of a hot point, and two thermocouples (one on each side of the cell) are positioned in the middle of the two central cells, which are expected to be unfavourable as regards the thermal exchange. The central cells are also equipped with a thermocouple under the positive pole.
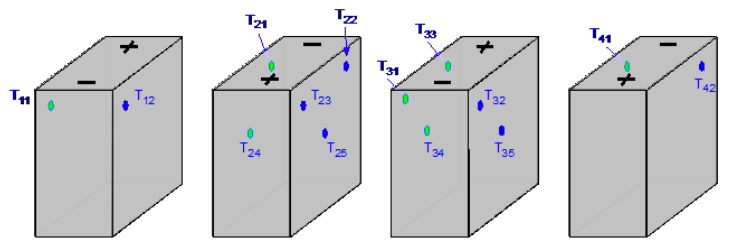

Figure 11: Position of the thermocouples during the thermal characterization

\subsection{Cooling plant with water}

A simple cooling circuit was realized using a cup with a water inlet and outlet. It is possible to adjust the water flow by the means of a tap. Four cells, at the distance of $1 \mathrm{~cm}$ one each other, as in the plant with air cooling, were dipped as a "pool boiling" in the cup, where the water goes in through a pipe connected to a tap of the waterworks, and lapped by the water. The water inlet is at the bottom of the cup, so that it cannot create waves and damage the cells. The water's level is about $1 \mathrm{~cm}$ lower than the top layer of the cells, where the poles are situated. It is possible to adjust the water flow by the means of the tap and to calculate its value using a scale and a timer. The inlet of the waste pipe is at the height of the level which is desired in the cup. The position of the thermocouples is the same of the previous plant. Also the monitoring and data acquisition system is the same of the cooling plant with air.

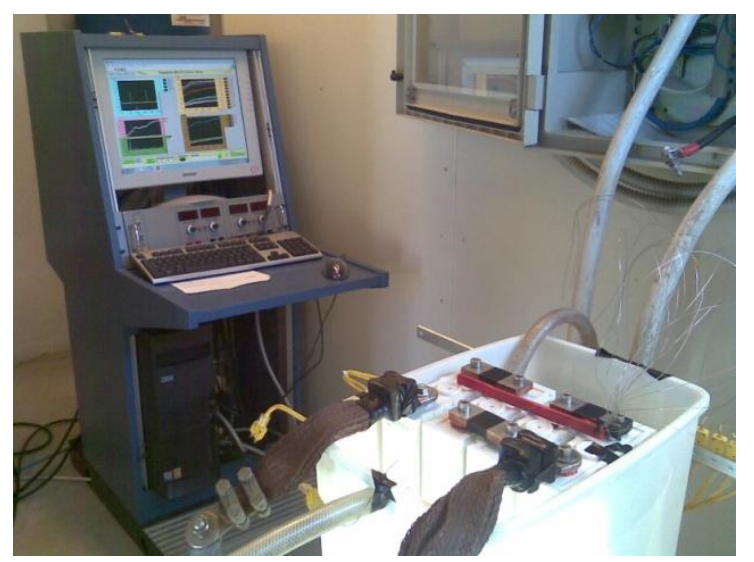

Figure 12: Thermal cooling by water

\subsection{Cooling tests}

The cooling tests were realized during the working of the batteries in the most critical operating conditions suggested by the manufacturer of the cells and confirmed by the electrical characterization: this happens at current rate $1 \mathrm{C}$ in charge and $3 \mathrm{C}$ in discharge. In the cooling test with air as cooling medium, a flow equal to $100 \mathrm{Nm}^{3} / \mathrm{h}$ was used, which is the order of flows that it is possible to reach by the means of little fans with low current absorption, while the cooling test with water as cooling medium was made at a flow equal to $100 \mathrm{l} / \mathrm{h}$, that is a flow value easy to reach by the means of a little pump. The results are shown in Fig. 13 and Fig. 14. 


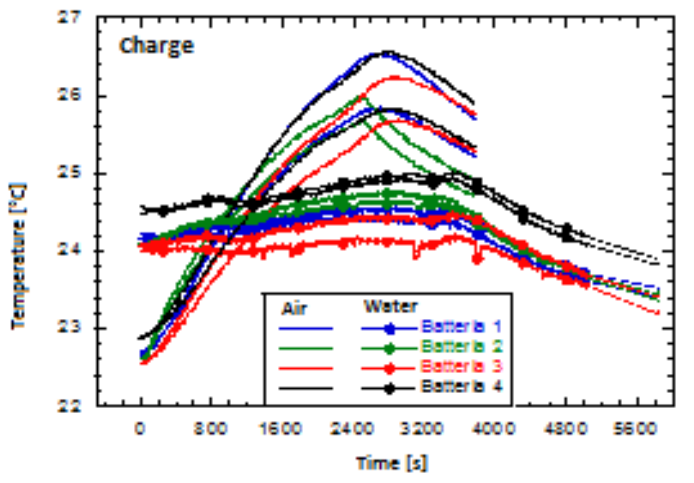

Figure 13: Cooling test during charge

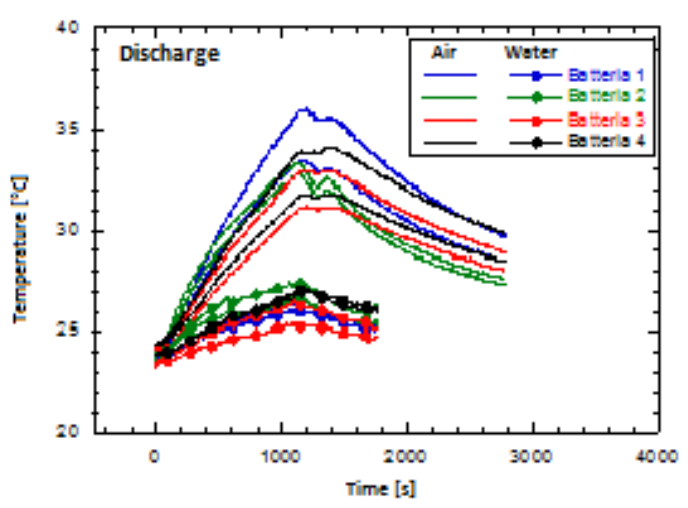

Figure 14: Cooling test during discharge

Both cooling systems proved to be efficient, in fact the temperature remained under the safe limits declared by the manufacturer of the cells $\left(+65{ }^{\circ} \mathrm{C}\right)$ and especially under the values registered in the similar tests performed during the thermal characterization without any cooling. The comparison between the two cooling fluids is in favour of water: in spite of this, air was chosen as medium for the cooling system in the battery modules, because it is anyway efficient but simpler and more economic than a water cooling system.

\section{Battery Management System}

A proper battery management system (BMS) with active balancing was developed by the University of Pisa in cooperation with ENEA [3], [6], [7]. It provides the functions of protection, monitoring, data acquisition and active balancing of the state of charge of the cells. The active balancing is realized by means of a DC/DC converter on the electronic board BMS. The converter input is the total voltage of the module $(12 \mathrm{~V})$ and its output is connected through a switch matrix (as shown in Fig. 15) to the lowest charged cell of the module. The current level during this balancing function can reach the value of $2 \mathrm{~A}$. Active balancing with high efficiency avoids wasting energy to restore the balanced condition.

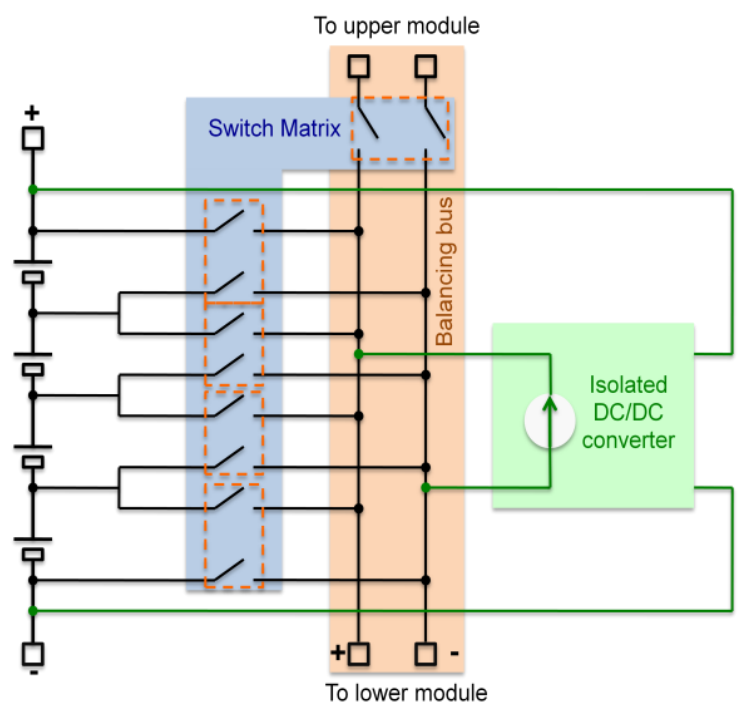

Figure 15: BMS architecture

When more modules are series connected to create a complete battery system, it is possible to transfer energy from a module to another of the chain: in this configuration, one electronic board is the master of the chain. During the initial programming of the electronic board, the module capacity is set and the function (as master or slave) can be defined, so the production of only one type of electronic board is required: these are aspects of standardization and they result in lower costs of production.

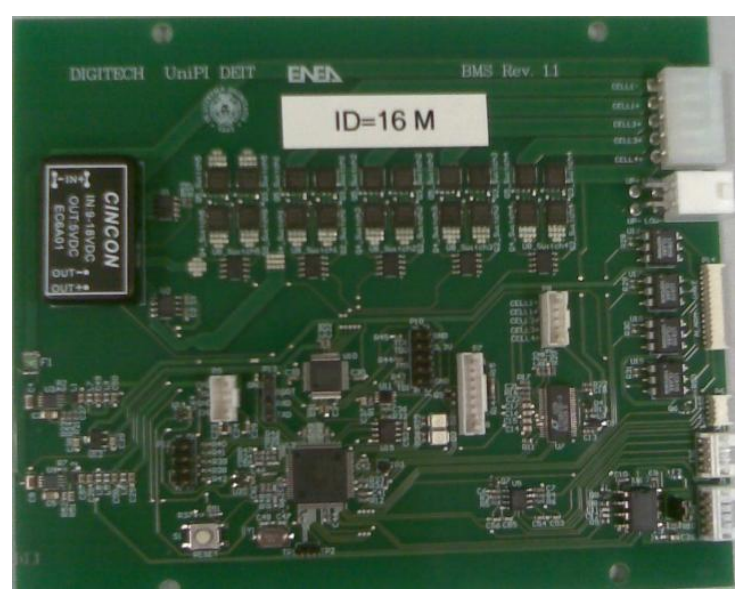

Figure 16: Electronic board

Further, the board receives the signals coming from the thermal sensors to manage the battery cooling. The particularly user friendly interface is shown in Fig. 17 relating to a complete battery system $48 \mathrm{~V}$ made by four $12 \mathrm{~V}$ modules series connected. 


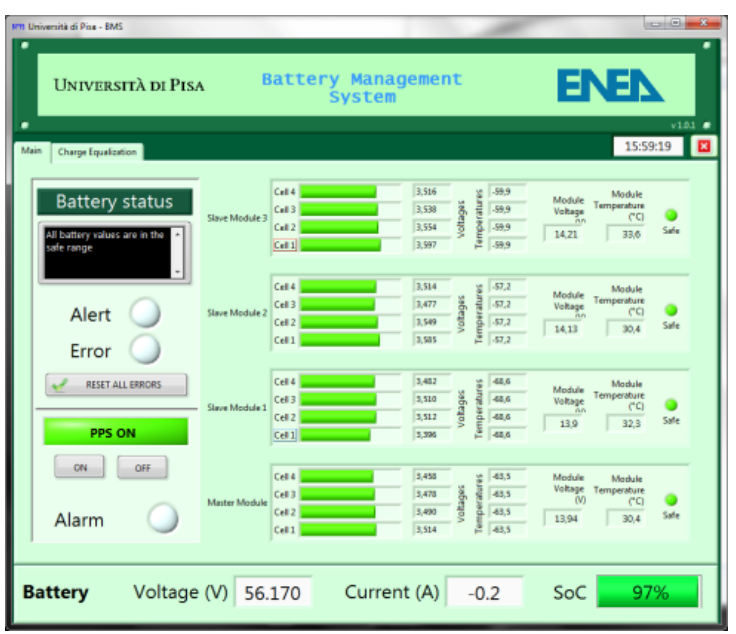

Figure 17: BMS user interface

\section{Realization of functional prototypes}

The battery module contains four cells, the electronic board BMS, the power and signal internal connections, the fans for the battery cooling and the connector to realize the external communication (with other modules if slave, PC, charger or vehicle control unit if master). Inside the module the cells are at the distance of $1 \mathrm{~cm}$ one each other so to create the ventilation channels. All the modules have an NTC sensor on each cell, situated where the thermo graphical analysis put on evidence the hot point, and three fans (each one $34.5 \mathrm{Nm}^{3} / \mathrm{h} 75.5 \mathrm{~Pa} @ 7000 \mathrm{rpm}$ ) on the cover of the case, which starts working when the temperature detected on a cell of the module is equal or bigger than $+45^{\circ} \mathrm{C}$ (this value is settable): the cooling system is optimized for the $100 \mathrm{Ah}$ module and oversized for the $30 \mathrm{Ah}$ and $60 \mathrm{Ah}$ modules, but the cooling system is maintained the same for any type of module as another factor of standardization. The standardization was not possible only for the case, due to the different dimensions of the cells. In fact, three different types of cases were realized: one case for the $30 \mathrm{Ah}$ module, one for the $60 \mathrm{Ah}$ module and one for the 100 Ah module.

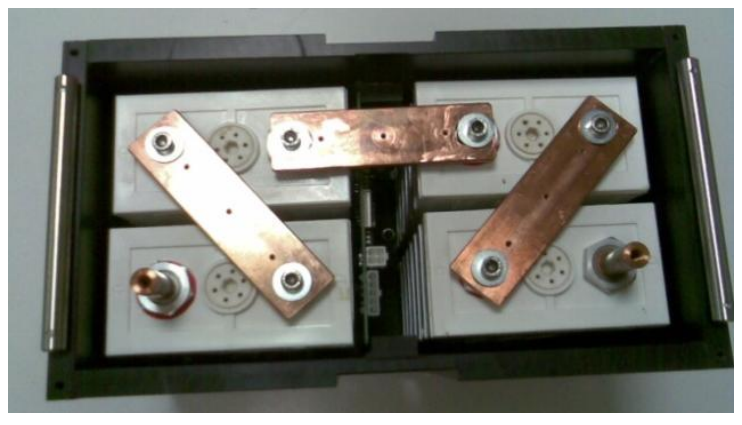

Figure 18: Inside view of the $30 \mathrm{Ah}$ and $60 \mathrm{Ah}$ module

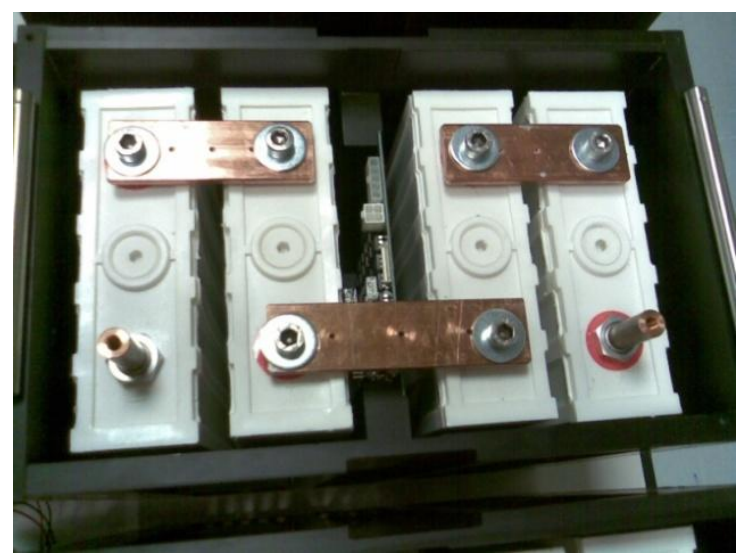

Figure 19: Inside view of the $100 \mathrm{Ah}$ module

The placement of the cells inside the little and medium size module is different from the large size module due to the optimization of the geometrical factor. Table 5 resumes the final characteristics of the modules.

Table 5: Main characteristics of the battery modules (part 1)

\begin{tabular}{|c|c|c|c|}
\hline $\begin{array}{c}\text { Module } \\
\text { size }\end{array}$ & Capacity & $\begin{array}{c}\text { Dimensions } \\
\text { LxWxH }\end{array}$ & Weight \\
\hline & {$[\mathrm{Ah}]$} & {$[\mathrm{mm}]$} & {$[\mathrm{kg}]$} \\
\hline small & 30 & $277 \times 160 \times 208$ & 8.3 \\
\hline medium & 60 & $297 \times 166 \times 236$ & 12.3 \\
\hline large & 100 & $310 \times 186 \times 318$ & 19.1 \\
\hline
\end{tabular}

Table 5: Main characteristics of the battery modules (part 2)

\begin{tabular}{|c|c|c|c|}
\hline $\begin{array}{c}\text { Energy } \\
\text { density }\end{array}$ & $\begin{array}{c}\text { Power } \\
\text { density }\end{array}$ & $\begin{array}{c}\text { Specific } \\
\text { energy }\end{array}$ & $\begin{array}{c}\text { Specific } \\
\text { power }\end{array}$ \\
\hline$\left[\mathrm{Wh} / \mathrm{dm}^{3}\right]$ & {$\left[\mathrm{W} / \mathrm{dm}^{3}\right]$} & {$[\mathrm{Wh} / \mathrm{kg}]$} & {$[\mathrm{W} / \mathrm{kg}]$} \\
\hline 42 & 125 & 47 & 139 \\
\hline 66 & 198 & 63 & 188 \\
\hline 70 & 210 & 67 & 201 \\
\hline
\end{tabular}

Fig. 20 shows the realization of the modules.

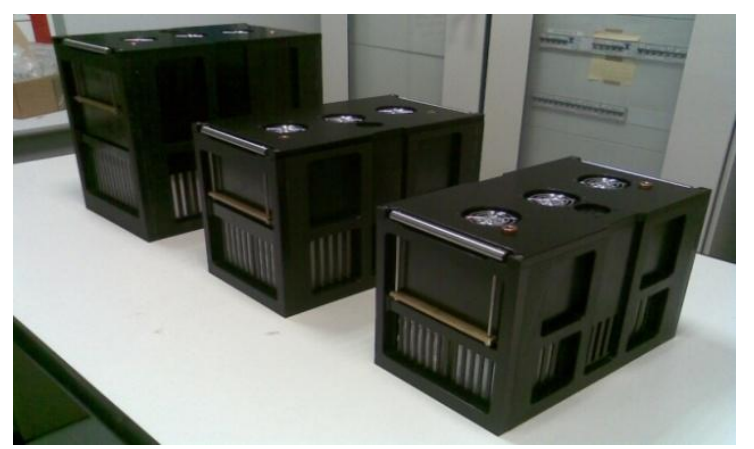

Figure 20: Standard modules: $100 \mathrm{Ah}$ (left), $60 \mathrm{Ah}$ (medium) and $30 \mathrm{Ah}$ (right) 


\section{Conclusions}

A little size battery module ( $30 \mathrm{Ah})$, a medium size battery module $(60 \mathrm{Ah})$ and a large size battery module $(100 \mathrm{Ah})$ were realized for the application in the field of off-road electric vehicles: the voltages $(48,96,192 \mathrm{~V})$ and capacities $(120,180 \mathrm{Ah})$ of this type of vehicles can be obtained by the series/parallel connection of the standard modules. As a demonstrator, a complete battery system $48 \mathrm{~V}-100 \mathrm{Ah}$ was also realized: it is made by four modules large size series connected, each module has its own BMS, one module has the master function. The modules can also be used as starting lighting ignition batteries instead of the equivalent lead batteries. After this first realization as functional demonstrators, the modules will be tested to validate their performances and reliability and suggest modifications for the optimization: this step will be made in cooperation with industrial partners in the prospect of a future commercialization.

\section{Acknowledgments}

This work is supported by the Italian Ministry of Economic Development in the framework of the Program Agreement for the Research on Electric System.

\section{References}

[1] M. Brenna, M. C. Falvo, F. Foiadelli, L. Martirano, F. Massaro, D. Poli, A. Vaccaro, "Challenges in Energy Systems for the Smart-Cities of the Future", IEEE Energycon 2012, 9-12 September 2012, Florence

[2] M. Giuntoli, D. Poli, "Optimized thermal and electrical scheduling of a Large Scale Virtual Power Plant in the presence of energy storages", IEEE Transactions on Smart Grid, 2013. DOI: 10.1109/TSG.2012.2227513

[3] F. Baronti, G. Fantechi, R. Roncella, R. Saletti, G. Pede and F. Vellucci, "Design of the Battery Management System of $\mathrm{LiFePO}_{4}$ Batteries for Electric Off-Road Vehicles," in 2013 IEEE International Symposium on Industrial Electronics (ISIE), 2013, pp. 1-6.

[4] F. Vellucci, G. Pede, " Sviluppo di moduli batterie litio-ioni per avviamento e trazione non automotive", http://www.enea.it, Report Ricerca di Sistema Elettrico n. 2011/27

[5] M. Ceraolo, T. Huria, C. Zappacosta, "Sviluppo di moduli integrati, completi di BMS", http://www.enea.it, Report Ricerca di Sistema Elettrico n. 2011/318
[6] F. Baronti, G. Fantechi, R. Roncella, R. Saletti, "Sviluppo di un BMS (Battery Management System) con sistema di bilanciamento attivo per sistema batterie al LiFePO4 da 48Vn - 100Ah", http://www.enea.it, Report Ricerca di Sistema Elettrico n. 2012/088

[7] F. Baronti, G. Fantechi, R. Roncella, R. Saletti, "Progettazione definitiva del BMS per batterie d'avviamento e trazione non automotive", http://www.enea.it, Report Ricerca di Sistema Elettrico n. 2012/089

\section{Authors}

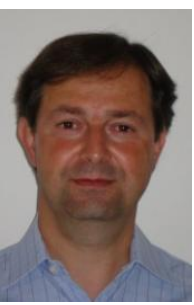

Francesco Vellucci has been working in the ENEA's "Low Environmental Impact Vehicles" Laboratory, especially in the section relating to electrochemical batteries and supercapacitors. He graduated in mechanical engineering (with honors) at the Rome University "La Sapienza" (1999) and started working at ENEA in 2009. Previously he worked in the field of industrial combustion and electric traction, especially marine engines electrically propelled.

Giovanni Pede is the Head of Enea's "Low Environmental Impact Vehicles" Laboratory. He graduated in mechanical engineering at the Rome University "La Sapienza" (1978) and started working at ENEA in 1984 on PEC reactor and renewable sources. Since 1992 he has been working and managing national and international projects on vehicles, especially on the use of hydrogen for traction and electric and hybrid vehicles.

Francesco D'Annibale is a lead research engineer at ENEA Laboratory of Thermal FluidDynamics Applied To Energy Systems of the Technical Unit for Advanced Technologies for Energy And Industries. He received his master's degree in nuclear engineering from the University of Rome "La Sapienza" in 1983, and started his research work at ENEA in

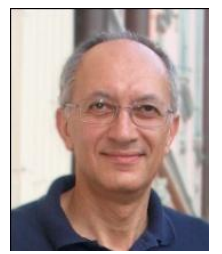
1984. He was involved in many aspects of heat and mass transfer such as: two-phase critical flows, critical heat flux, direct contact condensation and boiling, boiling in micro-gravity, bubble rising velocity, fused salt drainage, emergency spray 
cooling, heat transfer and corrosion of nanofluids.

\begin{abstract}
Andrea Mariani is research engineer at ENEA Laboratory of Thermal Fluid-Dynamics Applied To Energy Systems of the Technical Unit for Advanced Technologies for Energy And Industries. He received his $\mathrm{Ph} . \mathrm{D}$ in nuclear engineering from the University of Rome "La Sapienza" in 1985. He worked on transient critical heat flux, high heat flux experiments, critical heat flux, heat transfer enhancement, fusion reactors thermal hydraulics, rewetting, micro tubes thermalhydraulics, heat pipes for solar cooling, Heat transfer in nanofluids and cooling for battery in automobiles. Dr. Mariani is Author of 70 refereed journal and conference publication, Editors of three conference proceeding. Member of Scientific Council of International Centre for Heat and Mass Transfer
\end{abstract}

Roberto Roncella received the M.Sc. degree in electronic engineering and the Ph.D. degree from the University of Pisa, Italy, in 1984 and 1989, respectively. $\mathrm{He}$ served in the Italian Navy as an Officer with technical functions. In 1990, he became a Researcher with the Department of Information Engineering, University of Pisa, where he is currently an Associate Professor with the Faculty of Engineering. His main research interests are in the field of verylarge-scale-integration integrated circuits and on the design of highperformance digital and analog electronic circuits for astrophysics, automotive, and biomedical applications.

Roberto Saletti received the Dr.Ing. degree (with honors) in electronic engineering from the University of Pisa, Italy, in 1981. From 1983 to 1992, he was with the National Research Council as a Research Scientist. In 1987, he was with the Cornell University, Ithaca, NY, as a Visiting Scientist. In 1992, he became Associate Professor of digital system electronics with the Faculty of Engineering, University of Pisa. In 2001, he was appointed Full Professor of electronics with the University of Pisa, where he is currently working. His main research activities are in the fields of design and test of high-performance integrated circuits, such as highresolution delay-line circuits, and of electronic systems for automotive and nautical applications. His most recent works are related to the development of data acquisition and measurement systems for cruising boats and innovative models and electronic control systems of Li-ion batteries for the electrical propulsion of vehicles.

Federico Baronti received the M.Sc. and Ph.D. degrees in electronic engineering from the University of Pisa, Pisa, Italy, in 2001 and 2005, respectively. Currently, he is an assistant professor at the Department of Information Engineering, University of Pisa. His research topics include the design of embedded electronic systems for biomedical, automotive, and marine applications. More recent activities concern Li-ion battery modelling and the development of novel battery monitoring and management systems. Other fields of interests involve the design of very-largescale-integration integrated circuits for high-resolution and reliable time reference generation and the development of multichannel data acquisition and processing systems.

Gabriele Fantechi received the B.Sc. and M.Sc. degrees with honors in Electronic Engineering from the University of Pisa, Italy, in 2007 and 2009 respectively. Currently, he is a $\mathrm{PhD}$ student in Ground Vehicles at the same university. His research topics include the design of electronic systems for the management of batteries on electric and hybrid vehicles, as well as alternative fuels combustion engines control units. He also deals with electronic measuring instrumentation and data acquisition on ground vehicles and boats.
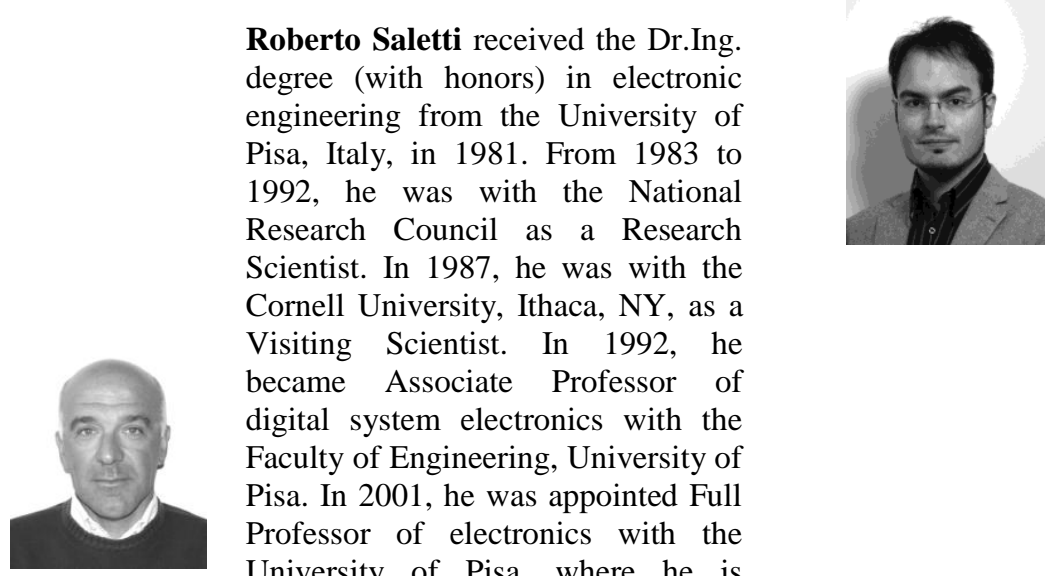